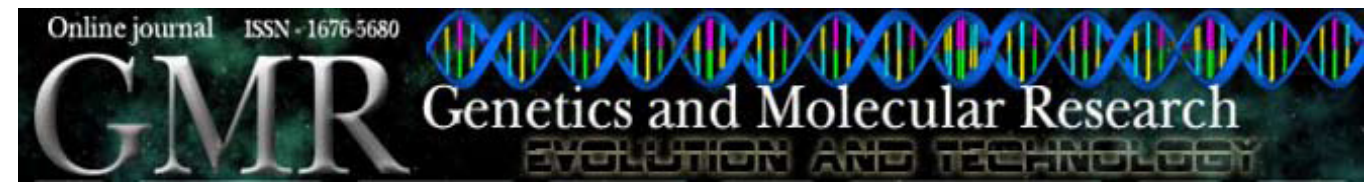

\title{
Toxoplasma gondii: cloning, sequencing, expression, and antigenic characterization of ROP2, GRA5 and GRA7
}

\author{
M. Igarashi ${ }^{1}$, F. Kano ${ }^{1}$, K. Tamekuni ${ }^{1}$, P.M. Kawasaki ${ }^{1}$, I.T. Navarro ${ }^{1}$, \\ O. Vidotto ${ }^{1}$, M.C. Vidotto ${ }^{1}$, R.Z. Machado ${ }^{2}$ and J.L. Garcia ${ }^{1}$ \\ ${ }^{1}$ Departamento de Medicina Veterinária Preventiva, \\ Universidade Estadual de Londrina, CCA, Campus Universitário, \\ Londrina, PR, Brasil \\ ${ }^{2}$ Departamento de Patologia Veterinária, \\ Universidade Estadual de São Paulo Julio de Mesquita Filho, \\ Jaboticabal, SP, Brasil \\ Corresponding author: J.L. Garcia \\ E-mail: jlgarcia@uel.br
}

Genet. Mol. Res. 7 (2): 305-313 (2008)

Received December 18, 2007

Accepted February 12, 2008

Published April 8, 2008

ABSTRACT. Toxoplasma gondii is an intracellular obligate protozoan, which infects humans and warm-blooded animals. The aim of the present study was to clone the rop 2 , gra5 and gra 7 genes from $T$. gondii RH strain and to produce recombinant proteins. The rop2, gra5 and gra 7 gene fragments produced by polymerase chain reaction were cloned into the $\mathrm{pET} 102 / \mathrm{D}-\mathrm{TOPO}^{\circledR}$ vector which contains thioredoxin and polyhistidine tags at the $\mathrm{C}$ - and $\mathrm{N}$-ends, respectively, and is expressed in Escherichia coli BL21(DE-3). The expression fusion proteins were found almost entirely in the insoluble form in the cell lysate. These recombinant proteins were purified with an Ni-NTA column. Concentrations of the recombinant antigens produced in the E. coli BL21-star ranged from 300 to $500 \mu \mathrm{g} / \mathrm{mL}$ growth media, which was used to immunize rabbits. We observed an identity ranging from 96 to $97 \%$ when nucleotide sequences were compared to GenBank database sequences. Immunocharacterization of proteins was made by indirect immunofluorescence assay. These 
proteins will be used for serodiagnosis and vaccination.

Key words: Toxoplasma gondii; ROP2; GRA5; GRA7; Cloning; Expression; Antigenic characterization

\section{INTRODUCTION}

Toxoplasma gondii is an intracellular obligate protozoan that infects humans and warm-blooded animals. Humans become infected by three primary ways: congenitally, ingestion of raw or undercooked meat containing tissue cysts, and ingestion of water contaminated with sporulated oocysts from infected cat feces (Dubey, 1996).

The T. gondii parasite belongs to the Apicomplexa phylum. A characteristic of this phylum is the apical complex including the secretory organelles micronemes, dense granules, and rhoptries. The dense granules and rhoptries have an essential role in the survival and invasion of the host cells.

The ROP2 protein which has a molecular mass of 54-55 $\mathrm{kDa}$ was recognized by a human T-cell clone isolated from an immune donor, that was specific for the parasite and produced high levels of IFN- $\gamma$ (Saavedra and Herion, 1991; Saavedra et al., 1991); this corresponds to the rhoptry family antigens. The GRA5 and GRA7 proteins from dense granules have molecular masses of approximately 21 and $29 \mathrm{kDa}$, respectively (Leriche and Dubremetz, 1990, 1991; Lecordier et al., 1993; Jacobs et al., 1998). These proteins are important in cell invasion, maintenance of the parasitophorous vacuole, and survival of the parasite after cellular invasion (Charif et al., 1990; Achbarou et al., 1991; Dubremetz and Schwartzman, 1993; Cesbron-Delauw, 1994; Metsis et al., 1995; Carruthers et al., 1999). Additionally, ROP2 (Vercammen et al., 2000), GRA5 (Tilley et al., 1997) and GRA7 (Ferguson et al., 1999) have been found in all stages of the parasite. For all these reasons, ROP2, GRA5 and GRA7 were chosen for the present study.

The T. gondii recombinant protein production has been desirable for use either as a vaccine or for diagnosis (Aubert et al., 2000).

The purpose of the present study was to clone genes rop 2 , gra5, and gra7 from $T$. gondii in expression vectors to produce recombinant proteins. Additionally, the nucleotide sequences were evaluated and the recombinant proteins characterized.

\section{MATERIAL AND METHODS}

\section{Toxoplasma gondii strain}

The RH strain was used in the experiment. DNA from tachyzoites of the RH strain (Sabin, 1941) was used for plasmid construction. This strain was passed weekly in our laboratory by mouse intraperitoneal passage. Tachyzoites of the RH strain were obtained from peritoneal fluid of infected Swiss Webster mice. The material was passed three times through a 26-gauge needle, washed twice with $10 \mathrm{mM}$ phosphate-buffered saline (PBS), $\mathrm{pH} 7.5$, and centrifuged. The pellet was resuspended and washed twice in PBS; after washing, tachyzoites were prepared at a concentration of $10^{5} / \mathrm{mL}$ prior to DNA extraction. DNA extraction was performed according to the Qiagen protocol. 


\section{Cloning of the rop2, gra5 and gra7 genes and DNA sequence analysis}

The entire gra5, gra7 and rop2 open reading frames were amplified from $T$. gondii $\mathrm{RH}$ genomic DNA by polymerase chain reaction (PCR). The DNA sequences were obtained from the GenBank database (accession number: L06091-GRA5; Y13863-GRA7; Z36906-ROP2). The primers used were rop 2 FW (5'-CACC ATG GAA AAC TGT GCG TCG GTC-3') and RW (5'-TGC CGG TTC TCC ATC AGT TTG-3'), gra5 FW (5'-CACC ATG GCG TCT GT AAA ACG CGT C-3') and RW (5'-CTC TTC CTC GGC AAC TTC TTC-3'), and gra 7 FW (5'- CACC AT GGC CCG CCG ACA CGC AAT TTT) and RW (5'-CTG GCG GGC ATC CTC CC). The CACC sequence from the 5 ' end of the forward primer anneals to the overhang sequence GTGG in pET102/D-TOPO ${ }^{\circledR}$ vector $(6.3 \mathrm{~kb})$ (Invitrogen, Carlsbad, CA, USA). PCR was carried out in a total volume of $50 \mu \mathrm{L}$, containing $50 \mathrm{ng}$ DNA template, $1 \mu \mathrm{L}$ each of the primers at $20 \mathrm{pmol}, 200 \mu \mathrm{M}$ of each deoxynucleoside triphosphate, $1 \mathrm{X} P f x$ platinum buffer, $0.5 \mu \mathrm{L} 50 \mathrm{mM}$ magnesium sulfate, $0.5 \mathrm{X}$ enhancer solution (Invitrogen), and $2.5 \mathrm{U} P f x$ platinum DNA polymerase (Invitrogen Life Technologies). PCR conditions were as follows: $94^{\circ} \mathrm{C}$ for $5 \mathrm{~min}$, followed by 30 cycles at $94^{\circ} \mathrm{C}$ for $1 \mathrm{~min}$, annealing at $59^{\circ} \mathrm{C}(\mathrm{rop} 2), 59^{\circ} \mathrm{C}\left(\mathrm{gra}\right.$ ), and $55^{\circ} \mathrm{C}$ (gra $)$ for $1 \mathrm{~min}$, and $68^{\circ} \mathrm{C}$ for $1 \mathrm{~min}$, followed by a final extension at $68^{\circ} \mathrm{C}$ for $7 \mathrm{~min}$ in a thermal cycler (Gene Amp PCR System 9700/ Perkin Elmer). The amplified DNA was visualized on 1.0\% agarose gels stained with ethidium bromide. A 100-bp ladder (Promega, Madison, WI, USA) was used as a standard for determining the molecular weight of PCR products. PCR products were quantified; $20 \mathrm{ng}$ was used as an insert in the pET102/D-TOPO ${ }^{\circledR}$ vector following manufacturer recommendations. Chemically competent Escherichia coli host strain TOP10 cells (Invitrogen) were transformed with $3 \mu \mathrm{L}$ of the cloning reaction. Next, $200 \mu \mathrm{L}$ of transformed bacterium culture was spread on selective plates containing $100 \mu \mathrm{g}$ ampicillin and incubated at $37^{\circ} \mathrm{C}$, overnight. These positive clones were grown in Luria Bertani broth containing ampicillin, before extraction of the plasmid by alkaline lysis (Sambrook et al., 1989). The presence of rop 2, gra 5 and gra 7 inserts were confirmed by restriction digestion of recombinant plasmids with HindIII (rop2), BamHI (gra5 and gra7), and by PCR, using rop2, gra5 and gra 7 and pET102/D-TOPO ${ }^{\circledR}$ (Trx Fus forward: 5'-TTCCTCGACGCTAACCTG-3' and $T 7$ reverse: 5'-TAGTTATTGCTGAGCGGTGG-3') primers. Sequence analyses were performed on all three cloned genes. The sequences were submitted to BLASTn and BLASTx (Altschul et al., 1990, 1997) through the NCBI website (http://www.ncbi.nlm.nih.gov/) to check sequence identity. DNA and amino acid sequence analyses were carried out with the computer programs "CAP3 Contig Assembly Program", "Clustal W (1.81) Multiple Sequence Alignments" and "Six Frame Translation of Sequence".

\section{Expression of the rop2, gra5 and gra7 in the Escherichia coli strain and purification of rROP2, rGRA5 and rGRA7}

E. coli BL21 was transformed with the recombinant plasmids pET102-rop2, pET102-gra5 and pET102-gra7. The BL21/pET102-rop2, BL21/pET102-gra5 and BL21/pET102-gra7 strains were grown to an optical density of 0.8 at $600 \mathrm{~nm}$; isopropyl-1- $\beta$-D-thiogalactopyranoside (Invitrogen Life Technologies) was added to a final concentration of $1 \mathrm{mM}$, and aliquots were removed at different times to choose the best time for expression. The cells were collected by centrifugation and the expressions were analyzed from soluble and insoluble fractions on $12 \%$ SDS-PAGE gels. For recombinant protein purification, the BL21/pET102-gene strains were grown for $5 \mathrm{~h}$ at $37^{\circ} \mathrm{C}$. The cells 
were collected by centrifugation and incubated in buffer containing $6 \mathrm{M}$ guanidine- $\mathrm{HCl}, 20 \mathrm{mM}$ $\mathrm{NaPO}_{4}$, and $10 \mathrm{mM}$ Tris- $\mathrm{HCl}$, $\mathrm{pH} 7.8\left(100 \mathrm{mM} \mathrm{NaH}_{2} \mathrm{PO}_{4}, 10 \mathrm{mM}\right.$ Tris-HCl, $8 \mathrm{M}$ urea, $\mathrm{pH}$ 8.0) for $1 \mathrm{~h}$ at room temperature to assure thorough cell lysis; the cell lysate was sonicated on ice with three 5 -s high-intensity pulses. The lysate was then centrifuged at 10,000 $\mathrm{g}$ for $30 \mathrm{~min}$ and the supernatant was transferred to Ni-NTA resin $\left(\right.$ Qiagen $\left.^{\circledR}\right)$, previously washed with denaturing-binding buffer $(8 \mathrm{M}$ urea, $20 \mathrm{mM} \mathrm{NaPO}_{4}, 10 \mathrm{mM}$ Tris-HCl, $\mathrm{pH}$ 7.8). The supernatant and resin were incubated for $1 \mathrm{~h}$ with rotation. After centrifugation at 2,000 rpm (in a microcentrifuge), the resin was washed twice with denaturing-binding buffer, and twice with denaturing wash buffer $\left(100 \mathrm{mM} \mathrm{NaH}_{2} \mathrm{PO}_{4}, 10 \mathrm{mM}\right.$ Tris-HCl, $8 \mathrm{M}$ urea, $\mathrm{pH}$ 6.3). The proteins were eluted using elution buffer $\left(100 \mathrm{mM} \mathrm{NaH}_{2} \mathrm{PO}_{4}, 10\right.$ $\mathrm{mM}$ Tris-HCl, $8 \mathrm{M}$ urea, $\mathrm{pH}$ 4.5). The protein contents of the purified rROP2, GRA5, and GRA7 were measured using the Bradford (1976) method and analyzed on 12\% SDS-PAGE gels.

\section{SDS-PAGE and Western blotting}

The lysates of recombinant $E$. coli and the purified rROP2, rGRA5, and rGRA7 were separated on a $12 \%$ SDS-PAGE gel. As positive control, tachyzoites of the T. gondii RH strain were lysed by boiling in Laemmli sample buffer, and separated on a 12\% SDS-PAGE gel (Laemmli, 1970). The gels were either stained with Coomassie blue or were used for Western blots. For Western blots, proteins were transferred on to nitrocellulose membranes (Pharmacia Biotech) (Towbin et al., 1979). After transfer, the nitrocellulose membrane was blocked in a blocking solution ( $7 \mathrm{mM} \mathrm{Na}_{2} \mathrm{HPO}_{4}, 3 \mathrm{mM} \mathrm{NaH} \mathrm{PO}_{4}, 140 \mathrm{mM} \mathrm{NaCl}$ and $5 \%$ dried skimmed milk) for $1 \mathrm{~h}$ at room temperature. After washing, strips of nitrocellulose membrane were incubated with pools of sera from inoculated animals diluted 1:50 in washing buffer $\left(7 \mathrm{mM} \mathrm{Na}_{2} \mathrm{HPO}_{4}, 3 \mathrm{mM} \mathrm{NaH}_{2} \mathrm{PO}_{4}\right.$, $140 \mathrm{mM} \mathrm{NaCl}$ and $1 \%$ dried skimmed milk). After washing, strips were incubated for $1 \mathrm{~h}$ at room temperature with peroxidase-labeled anti-rabbit IgG antibody (diluted 1:10,000 in washing buffer). The peroxidase activity was revealed using electrochemiluminescence (Amersham Pharmacia, Biotech). The reaction was stopped by washing in distilled water.

\section{Immunizations with rROP2, rGRA5 and rGRA7}

Six rabbits were maintained according to the National Institute of Health rules for use of laboratory animals. These animals, 2 for each recombinant protein, were used to obtain polyclonal antibodies. Each rabbit was immunized subcutaneously with $100 \mu \mathrm{g}$ protein, together with complete Freund's adjuvant, followed by three inoculations with incomplete Freund's adjuvant after 14 days. Five days after the last boost, the rabbits were bled, and the serum was separated, inactivated, and adsorbed on E. coli BL21 Star ${ }^{\mathrm{TM}}$ (DE-3). Control serum was obtained from a non-immunized animal.

The immune response against rROP2, rGRA5, and rGRA7 was analyzed by Western blotting using a pool of preimmune sera (dilution) and a pool of immune sera (1:5000).

\section{Indirect immunofluorescence assay}

Serum samples from immunized rabbits (2.4) were used. The indirect immunofluorescence assay was performed as described previously (Camargo, 1973). The rabbit serum samples were diluted 1:100 and incubated with slides, previously sensitized with 
tachyzoites, for $30 \mathrm{~min}$ at $37^{\circ} \mathrm{C}$. Afterward, the slides were washed thrice with PBS and then incubated for $30 \mathrm{~min}$ at $37^{\circ} \mathrm{C}$ with the secondary antibody, FITC-conjugated goat antirabbit IgG (Invitrogen, USA). After washing, the slides were mounted with 50\% glycerol in PBS and observed by immunofluorescence microscopy (Nikon).

\section{RESULTS}

\section{DNA sequence analysis of rop2, gra5, and gra 7}

Analysis of nucleotide sequences from rop2, gra5 and gra 7 of the T. gondii RH strain showed an identity of 96, 97, and 96\% with Z36906-ROP2, L06091-GRA5, and Y13863GRA7, respectively. The colonies obtained from cloning into pET102-TOPO were screened first by PCR with specific primers for the rop2, gra5, and gra7 gene and the vector; all clones showed the amplicon, as expected.

\section{Expression in Escherichia coli BL21 and purification under denaturing conditions}

The expression and purification of recombinant proteins are shown in Figure 1. The rROP2, rGRA5 and rGRA7 proteins showed a molecular mass ranging from 21 to $72 \mathrm{kDa}$. Concentrations of the recombinant antigens produced in the E. coli BL21-star ranged from 300 to $500 \mu \mathrm{g} / \mathrm{mL}$ of growth media.

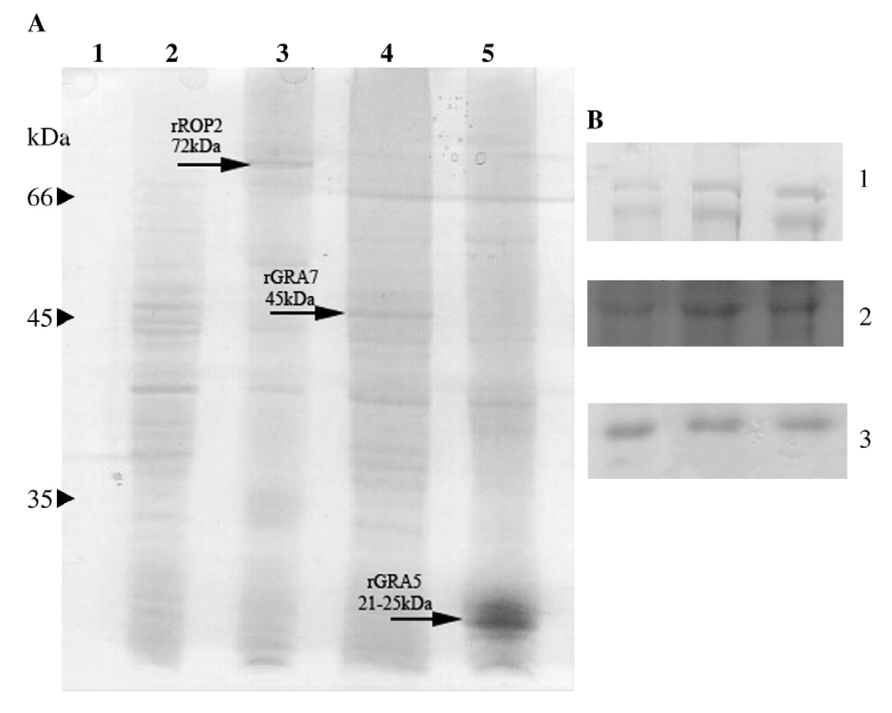

Figure 1. SDS-electrophoresis on $12 \%$ polyacrylamide gel of Escherichia coli extracts expression of pET102ROP2, pET102-GRA7, and pET102-GRA5 fusion proteins (panel A) and results of purification by denaturing conditions on $\mathrm{Ni}^{2+}$ (panel B). Panel A. Lane 1, molecular mass marker (Invitrogen); lane 2, lysate of induced culture of E. coli BL21 (DE3); lanes 3-5, protein cell extracts from E. coli strains BL21star + pET102/ROP2 or + pET102/ GRA7 and + pET102/GRA5, respectively, after $1 \mathrm{mM}$ isopropyl-1- $\beta$-thiogalactopyranoside induction of protein expression and further cultivation for $5 \mathrm{~h}$ at $30^{\circ} \mathrm{C}$. Panel B. His6-ROP2 (1), His6-GRA7 (2), and His6-GRA5 (3) fusion protein purified with $\mathrm{Ni}^{2+}$ columns. Molecular size standards are indicated on the left of the panel. 


\section{Antigenic characterization of the recombinant proteins}

In situ localization of rROP2, rGRA5, and rGRA7 by immunofluorescence is shown in Figure 2. ROP2 showed a typical polar stain and GRA5 and GRA7 showed a membrane staining. The Western blotting of rabbit sera is presented in Figure 3. The Western blotting for tachyzoites of RH strain showed a reaction against two antigens of 53 and $29 \mathrm{kDa}$ for ROP2, one of $32 \mathrm{kDa}$ for GRA5, and one antigen of $26.5 \mathrm{kDa}$ for GRA7.
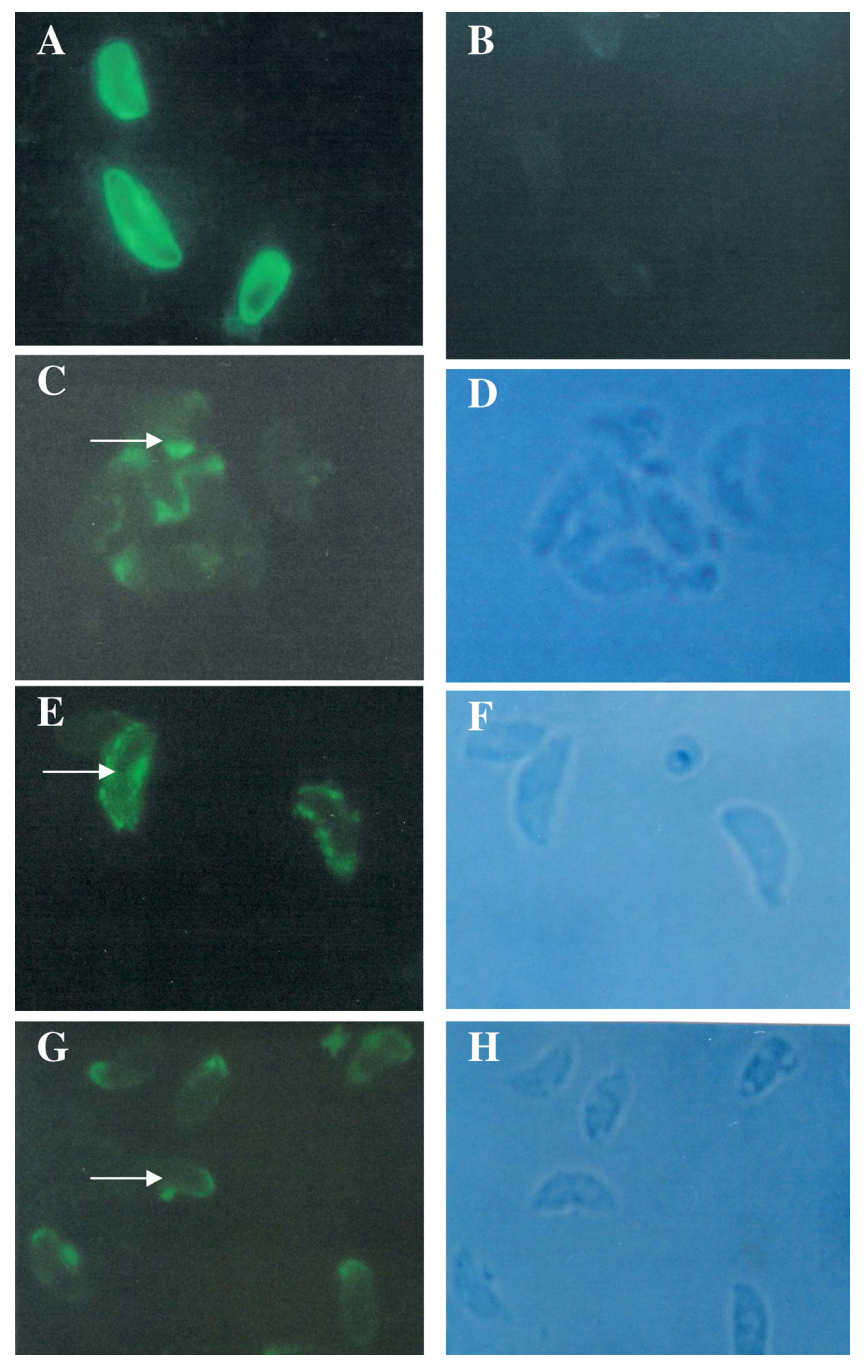

Figure 2. Indirect immunofluorescence localization of antigen detected by rabbit serum samples. Panel A. Extracellular tachyzoites detected by positive rabbit serum after infection with Toxoplasma gondii. Panel B. Extracellular tachyzoites exposed to negative rabbit serum. Panels C, E and G. Immunofluorescence images of $T$. gondii tachyzoites (arrows) detected by anti-ROP2, anti-GRA5 and anti-GRA7 antibodies, respectively. Panels D, $\mathbf{F}$ and $\mathbf{H}$. Immunofluorescence images correspond to the phase-contrast micrographs. 


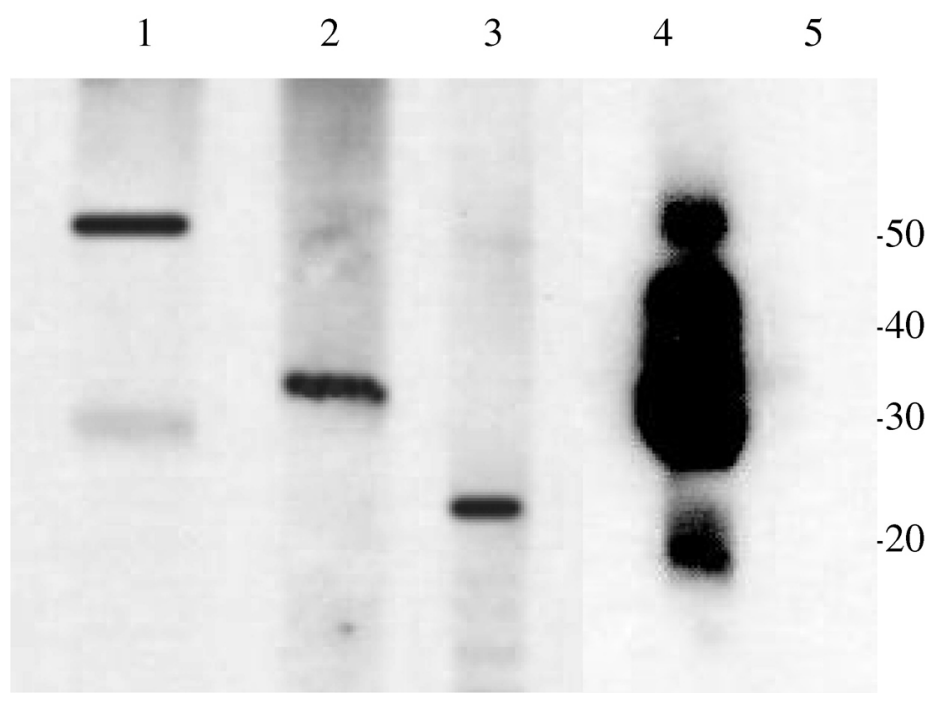

Figure 3. Western blotting using lysed tachyzoites of the Toxoplasma gondii $\mathrm{RH}$ strain, and separated on a $12 \%$ SDS-PAGE gel. Six rabbits, two for each recombinant protein, were used to obtain polyclonal antibodies. Lanes 1-3, The reactions were performed with sera from rabbit inoculated with rROP2, rGRA7, and rGRA5, respectively. The polyclonal antibodies from rROP2, rGRA7, and rGRA5 reacted with antigens with molecular masses ranging from 53 to $29 \mathrm{kDa}, 32 \mathrm{kDa}$, and $26.5 \mathrm{kDa}$, respectively. Lanes 4 and 5, Positive and negative controls. On the right of the panel are stated molecular mass ladders.

\section{DISCUSSION}

The present study cloned genes from two secretory organelles from $T$. gondii, dense granules and rhoptry. Analysis of sequence variation in the T. gondii rop2-, gra5- and gra7coding regions from Londrina-RH strain showed some heterogeneity in nucleotides and predicted amino acid sequences (data not shown), when compared to the RH strains from the GenBank. However, this heterogeneity neither changed reactivity in the indirect fluorescence antibody test nor immunoblotting to $T$. gondii tachyzoites.

The rROP2 $(72 \mathrm{kDa})$ and rGRA7 $(40-45 \mathrm{kDa})$ proteins showed a larger size than the expected molecular mass of the crude proteins. This result was observed previously with ROP2 and GRA7 recombinant proteins (Jacobs et al., 1998; Fischer et al., 1998) and with GRA1 recombinant protein (Supply et al., 1999). These findings could be explained by both fusion of the His-patch thioredoxin open reading frame $(13 \mathrm{kDa})$ and $6 \mathrm{X}$ His $(3 \mathrm{kDa})$ protein, and the sequences which were apparently not cleaved by the E. coli proteases (Jacobs et al., 1998). The proline content of the proteins (GRA7 with 5.5\% and ROP2 with 7.7\%) could contribute slightly to migration in SDS-PAGE (Bermudes et al., 1994; Jacobs et al., 1998). Despite this, rGRA5 (21-25 kDa) protein showed a very similar molecular mass for the protein expressed by $T$. gondii.

The cross-reactivity observed in the Western blotting result using polyclonal antibodies against recombinant proteins can be explained by the fact that there is a family of rhoptry antigens that share antigenic determinants (Sadak et al., 1988; Leriche and Dubremetz, 1991; 
Beckers et al., 1994; El Hajj et al., 2007); this has also been described for dense granule antigens (Cesbron-Delauw, 1994; Lecordier et al., 1995).

Fonjungo et al. (1998) related reactivity of monoclonal antibodies to recombinant rhoptry protein of Plasmodium falciparum (rRAP1) with fragments of that protein. Degradation of recombinant proteins were previously described (Stowers et al., 1995; Fonjungo et al., 1998). It probably occurs before purification of the recombinant proteins, possibly within $E$. coli cells following expression (Fonjungo et al., 1998). Additionally, autocatalysis could be occurring (Ridley et al., 1990). The protein degradation could explain the two bands observed in $\mathrm{rROP} 2$ purification (Figure 1B).

Hereafter, the recombinant proteins obtained will be used in vaccine studies and ELISA.

\title{
ACKNOWLEDGMENTS
}

\author{
Research supported by Fundação Araucaria (Grant No. 5541).
}

\section{REFERENCES}

Achbarou A, Mercereau-Puijalon O, Sadak A, Fortier B, et al. (1991). Differential targeting of dense granule proteins in the parasitophorous vacuole of Toxoplasma gondii. Parasitology 103 (Pt. 3): 321-329.

Altschul SF, Gish W, Miller W, Myers EW, et al. (1990). Basic local alignment search tool. J. Mol. Biol. 215: 403-410.

Altschul SF, Madden TL, Schaffer AA, Zhang J, et al. (1997). Gapped BLAST and PSI-BLAST: a new generation of protein database search programs. Nucleic Acids Res. 25: 3389-3402.

Aubert D, Maine GT, Villena I, Hunt JC, et al. (2000). Recombinant antigens to detect Toxoplasma gondii-specific immunoglobulin $\mathrm{G}$ and immunoglobulin $\mathrm{M}$ in human sera by enzyme immunoassay. J. Clin. Microbiol. 38: 1144-1150.

Beckers CJ, Dubremetz JF, Mercereau-Puijalon O and Joiner KA (1994). The Toxoplasma gondii rhoptry protein ROP 2 is inserted into the parasitophorous vacuole membrane, surrounding the intracellular parasite, and is exposed to the host cell cytoplasm. J. Cell Biol. 127: 947-961.

Bermudes D, Dubremetz JF, Achbarou A and Joiner KA (1994). Cloning of a cDNA encoding the dense granule protein GRA3 from Toxoplasma gondii. Mol. Biochem. Parasitol. 68: 247-257.

Bradford MM (1976). A rapid and sensitive method for the quantitation of microgram quantities of protein utilizing the principle of protein-dye binding. Anal. Biochem. 72: 248-254.

Camargo ME (1973). Introdução às técnicas de imunofluorescência. Instituto de Medicina Tropical, São Paulo, 60-61.

Carruthers VB, Moreno SN and Sibley LD (1999). Ethanol and acetaldehyde elevate intracellular $\left[\mathrm{Ca}^{2+}\right]$ and stimulate microneme discharge in Toxoplasma gondii. Biochem. J. 342 (Pt. 2): 379-386.

Cesbron-Delauw MF (1994). Dense-granule organelles of Toxoplasma gondii: their role in the host-parasite relationship. Parasitol. Today 10: 293-296.

Charif H, Darcy F, Torpier G, Cesbron-Delauw MF, et al. (1990). Toxoplasma gondii: characterization and localization of antigens secreted from tachyzoites. Exp. Parasitol. 71: 114-124.

Dubey JP (1996). Strategies to reduce transmission of Toxoplasma gondii to animals and humans. Vet. Parasitol. 64: 65-70.

Dubremetz JF and Schwartzman JD (1993). Subcellular organelles of Toxoplasma gondii and host cell invasion. Res. Immunol. 144: 31-33.

El Hajj H, Lebrun M, Arold ST, Vial H, et al. (2007). ROP18 is a rhoptry kinase controlling the intracellular proliferation of Toxoplasma gondii. PLoS Pathog. 3: e14.

Ferguson DJ, Jacobs D, Saman E, Dubremetz JF, et al. (1999). In vivo expression and distribution of dense granule protein 7 (GRA7) in the exoenteric (tachyzoite, bradyzoite) and enteric (coccidian) forms of Toxoplasma gondii. Parasitology 119 (Pt. 3): 259-265.

Fischer HG, Stachelhaus S, Sahm M, Meyer HE, et al. (1998). GRA7, an excretory $29 \mathrm{kDa}$ Toxoplasma gondii dense granule antigen released by infected host cells. Mol. Biochem. Parasitol. 91: 251-262.

Fonjungo PN, Stuber D and McBride JS (1998). Antigenicity of recombinant proteins derived from rhoptry-associated 
protein 1 of Plasmodium falciparum. Infect. Immun. 66: 1037-1044.

Jacobs D, Dubremetz JF, Loyens A, Bosman F, et al. (1998). Identification and heterologous expression of a new dense granule protein (GRA7) from Toxoplasma gondii. Mol. Biochem. Parasitol. 91: 237-249.

Laemmli UK (1970). Cleavage of structural proteins during the assembly of the head of bacteriophage T4. Nature 227: 680-685.

Lecordier L, Mercier C, Torpier G, Tourvieille B, et al. (1993). Molecular structure of a Toxoplasma gondii dense granule antigen (GRA 5) associated with the parasitophorous vacuole membrane. Mol. Biochem. Parasitol. 59: 143-153.

Lecordier L, Moleon-Borodowsky I, Dubremetz JF, Tourvieille B, et al. (1995). Characterization of a dense granule antigen of Toxoplasma gondii (GRA6) associated to the network of the parasitophorous vacuole. Mol. Biochem. Parasitol. 70: 85-94.

Leriche MA and Dubremetz JF (1990). Exocytosis of Toxoplasma gondii dense granules into the parasitophorous vacuole after host cell invasion. Parasitol. Res. 76: 559-562.

Leriche MA and Dubremetz JF (1991). Characterization of the protein contents of rhoptries and dense granules of Toxoplasma gondii tachyzoites by subcellular fractionation and monoclonal antibodies. Mol. Biochem. Parasitol. 45: 249-259.

Metsis A, Pettsersen E and Petersen E (1995). Toxoplasma gondii: characterization of a monoclonal antibody recognizing antigens of 36 and $38 \mathrm{kDa}$ with acid phosphatase activity located in dense granules and rhoptries. Exp. Parasitol. 81: 472-479.

Ridley RG, Takacs B, Etlinger H and Scaife JG (1990). A rhoptry antigen of Plasmodium falciparum is protective in Saimiri monkeys. Parasitology 101 (Pt. 2): 187-192.

Saavedra R and Herion P (1991). Human T-cell clones against Toxoplasma gondii: production of interferon-gamma, interleukin-2, and strain cross-reactivity. Parasitol. Res. 77: 379-385.

Saavedra R, de Meuter F, Decourt JL and Herion P (1991). Human T cell clone identifies a potentially protective 54-kDa protein antigen of Toxoplasma gondii cloned and expressed in Escherichia coli. J. Immunol. 147: 1975-1982.

Sabin AB (1941). Toxoplasmic encephalitis in children. J. Am. Med. Assoc. 116: 801-807.

Sadak A, Taghy Z, Fortier B and Dubremetz JF (1988). Characterization of a family of rhoptry proteins of Toxoplasma gondii. Mol. Biochem. Parasitol. 29: 203-211.

Sambrook J, Fritsch EF and Maniatis T (1989). Molecular cloning. Cold Spring Harbor Laboratory Press, New York, 1.25-1.58.

Stowers AW, Spring KJ and Saul A (1995). Preparative scale purification of recombinant proteins to clinical grade by isotachophoresis. Biotechnology 13: 1498-1503.

Supply P, Sutton P, Coughlan SN, Bilo K, et al. (1999). Immunogenicity of recombinant BCG producing the GRA1 antigen from Toxoplasma gondii. Vaccine 17: 705-714.

Tilley M, Fichera ME, Jerome ME, Roos DS, et al. (1997). Toxoplasma gondii sporozoites form a transient parasitophorous vacuole that is impermeable and contains only a subset of dense-granule proteins. Infect. Immun. 65: 4598-4605.

Towbin H, Staehelin T and Gordon J (1979). Electrophoretic transfer of proteins from polyacrylamide gels to nitrocellulose sheets: procedure and some applications. Proc. Natl. Acad. Sci. U. S. A. 76: 4350-4354.

Vercammen M, Scorza T, Huygen K, De Braekeleer J, et al. (2000). DNA vaccination with genes encoding Toxoplasma gondii antigens GRA1, GRA7, and ROP2 induces partially protective immunity against lethal challenge in mice. Infect. Immun. 68: 38-45. 